\title{
PENGGUNAAN ALAT PERMAINAN EDUKATIF (APE) DARI BOTOL PLASTIK DAN KORAN BEKAS UNTUK MENINGKATKAN KREATIVITAS
}

\author{
Zikra Hayati \\ Universitas Islam Negeri Ar-Raniry Banda Aceh \\ E-mail: zikra.hayati@ar-raniry.ac.id
}

Article received: 10 November 2018, Review process: 02 February 2019

Article published: 30 March 2019

\begin{abstract}
The aims of research to find out the development of early childhood creativity by using APE (Educational Playing) made by secondhand thing in RA Al-Ihsan Tgk Chik in Adan and to find out the types of APE that can be used to enhance early childhood creativity. Furthermore, The research was conducted because there are some problems indicate that early childhood has low development in creativity ability, teacher who have not used variety of APE, that impact for the children that less motivated, bored so that make less response for creativity development and activities in the class. The activities running in teaching and learning is not show that activities make stimulate children to think creatively, that is concluded from several creativity indicators are: the teacher has not made learning activities in to express children ideas, the child in RA has not been accustomed to creating something new, either to benefit secondhand thing use to create some APE. The type of research is classroom action research (CAR), the subject is early childhood, namely 6 children in grade A in RA Al-Ihsan Tgk Chik in Adan, in Pidie. Data collection techniques with Observation and Documentation. The results show that: (1) there is an enhancing children's creativity through APE from using second hand thing, as show that the percentage increase in the first cycle in the category of MB (Start to Grow) that is $45.83 \%$ and that was increase in Cycle II which was in BSB category (Developing Very Good) a percentage of $76.04 \%$. Based on the data analysis it can be concluded that using APE from second hand thing can develop children creativity, from MB category (Start Developing) that is $45.83 \%$ and to BSB category (Very Good Developing) which is a percentage of 76, 04\%. (2) The type of APE that used to improve children creativity in RA Al-Ihsan Tgk Chik in Adan, namely the type of APE that can develop aspects creative, namely: APE types of animals from plastic bottles and APE Geometry shapes and Numbering that is created by newspaper.
\end{abstract}

Keywords: Educational Playing; Creativity

Abstrak
Penelitian ini bertujuan untuk mengetahui peningkatan kreativitas AUD dengan menggunakan
Alat Permainan Edukatif dari bahan bekas di RA Al-Ihsan Tgk Chik di Adan dan untuk
mengetahui jenis APE yang digunakan untuk meningkatkan kreativitas AUD. Penelitian ini
dilakukan karena terdapat permasalahan rendahnya perkembangan kreativitas AUD, terlihat
dari guru belum menggunakan APE yang bervariasi, sehingga anak kurang termotivasi, bosan
sehingga respon terhadap aktifitas perkembangan kreativitas kurang berkembang, belum
Penggunaan Alat Permainan Edukatif dari Botol Plastik dan
Koran Bekas untuk Meningkatkan Kreativitas AUD


terlihatnya aktifitas yang memicu anak untuk berfikir kreatif dari beberapa indikator yang tampak yaitu: guru belum membuat aktifitas pembelajaran dalam hal mengungkapkan ide/gagasannya, anak di RA tersebut belum dibiasakan untuk menciptakan sesuatu hal yang baru, baik berupa pemanfaatan bahan bekas yang dapat digunakan untuk pembuatan APE. Jenis Penelitian yang dilakukan ialah penelitian tindakan kelas (PTK), Subjek penelitian adalah AUD yaitu AUD kelompok A yang anak didiknya berjumlah 6 orang di RA Al-Ihsan Tgk Chik di Adan Kabupaten Pidie. Tekhnik pengumpulan data dengan Observasi dan Dokumentasi. Hasil Penelitian menunjukkan bahwa: (1) terdapat peningkatan kreativitas anak melalui APE dari bahan bekas, dilihat dari peningkatan persentase pada siklus I berada pada kategori MB (Mulai Berkembang) yaitu 45,83\% terjadi peningkatan di Siklus II yang berada pada kategori BSB (Berkembang Sangat Baik) yaitu persentase sebesar 76,04\%. Berdasarkan Analisis data dapat disimpulkan bahwa penggunaan APE dari bahan bekas dapat meningkatkan kreativitas AUD, pada siklus I berada pada kategori MB (Mulai Berkembang) yaitu 45,83\% dan Siklus II yang berada pada kategori BSB (Berkembang Sangat Baik) yaitu persentase sebesar 76,04\%. (2) Jenis APE yang digunakan untuk meningkatkan kreativitas AUD di RA Al-Ihsan Tgk Chik di Adan, yaitu jenis APE yang mengembangkan aspek perkembangan kreatiftas AUD, yaitu: APE jenis-jenis hewan dari botol plastik dan APE bentuk Geometri dan Bilangan dari Korang Bekas.

Kata Kunci: APE; Kreativitas AUD

\section{PENDAHULUAN}

Pendidikan Anak Usia Dini (PAUD) pada hakikatnya merupakan suatu tujuan pendidikan yang diselenggarakan untuk membantu pertumbuhan dan perkembangan anak atau lebih menitik beratkan pada aspek perkembangan anak. Oleh karena itu, PAUD dianggap suatu tempat pendidikan yang memberi kesempatan kepada anak untuk mengembangkan kepribadian potensi anak secara maksimal. Akibatnya, lembaga PAUD perlu memfasilitasi berbagai aspek perkembangan anak, yaitu: kognitif, bahasa, sosial, emosi, motorik, fisik, kreativitas, agama dan spiritual.

Senada dengan tujuan di atas, Solehuddin dalam Suyadi (2016: 19) dan ditegaskan oleh Suyanto (2005), adapun tujuan PAUD ialah mengembangkan seluruh potensi anak (the whole child), dengan memfasilitasi pertumbuhan dan perkembangan anak secara menyeluruh. Lembaga PAUD bertanggung jawab untuk memfasilitasi anak untuk mengembangkan seluruh aspek kepribadiannya baik dari kognitif, bahasa, sosial, emosi, motorik, fisik, kreativitas, agama dan spiritual.

Berdasarkan gambaran di atas, dapat disimpulkan bahwa secara praktis, cara menfasilitasi untuk mengembangkan aspek perkembangan anak sebagai berikut:

a. Meningkatkan mutu PAUD (kurikulum disusun sesuai perkembangan AUD) 
b. Memperbaiki kualitas Guru PAUD (dari segi metode, model dan strategi pembelajaran)

c. Sarana dan prasarana di lembaga AUD

d. APE (Alat Peraga Edukatif) untuk setiap aspek perkembangan anak

Untuk meningkatkan mutu PAUD, guru AUD perlu memahami prinsip yang merupakan fondasi dasar bagi pendidik dalam belajar-mengajar. Sejalan dengan yang diungkapkan oleh David Elkind dalam Hass (1993) bahwa belajar-mengajar dikatakan interaktif di mana guru melayani anak dan berfungsi sebagai perantara antara anak dan materi atau alat belajar (APE) agar konteks yang disampaikan pada anak akan sampai dengan tepat dan benar. Dengan pola ini maka guru dan calon guru PAUD akan memerankan fungsi interaktif secara efektif sehingga guru PAUD dapat memilih materi, APE, jenis permainan bagi setiap anak untuk mengembangkan aspek perkembangan individual diri anak.

Pentingnya APE dalam suatu kegiatan belajar anak untuk memperjelas materi yang disampaikan oleh guru. Sebagai contoh, guru ingin menjelaskan konsep bentuk dasar pada anak seperti petak, bulat, segitiga, oval, besar, kecil dll, maka akan lebih terarah jika guru langsung menjelaskan dengan anak melakukan proses mengamati, membandingkan, memasangkan, mencocokkan, menggabungkan dibandingkan guru hanya menjelaskan secara lisan dengan hanya bercerita. Anak hanya akan mendengarkan guru, menghayalkan bagaimana bentuknya, meniru ucapan guru tanpa tahu bagaimana jenis-jenis bentuk yang dimaksudkan guru. Maka akan sangat berbeda jika APE yang digunakan, pembelajaran akan lebih tepat sasaran pada tujuan yang diinginkan.

Berdasarkan gambaran di atas, dapat digarisbawahi bahwa dengan memanfaatkan APE anak menguasai kemampuan membandingkan, membedakan, mencocokkan, mengkreasikan suatu benda, dan pada level yang lebih tinggi yaitu melakukan eksperimen pada balok warna tersebut. APE berupa balok warna merupakan alat yang sangat potensial untuk mengembangkan berbagai aspek perkembangan anak, contohnya: kognitif dan keterampilan yang dikembangkan, pengenalan bentuk dan warna, untuk melatih konsentrasi, dan motorik halus anak. 


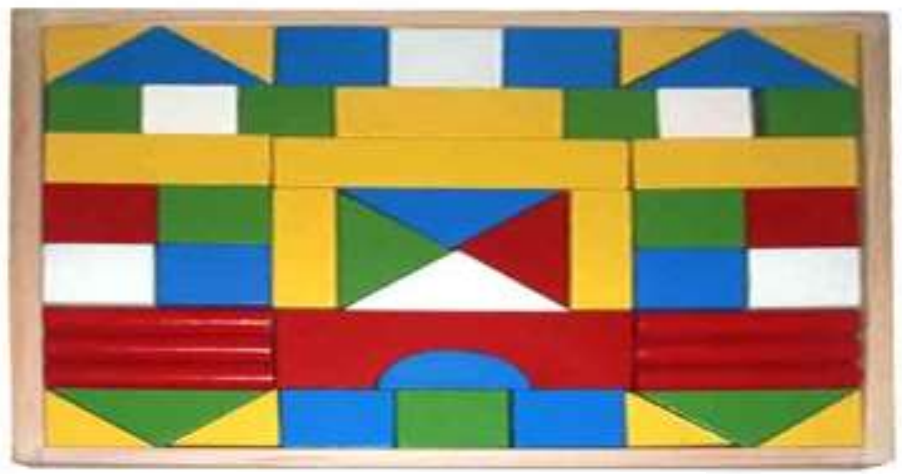

\section{Gambar 1. Balok}

APE balok warna merupakan alat yang berfungsi meningkatkan motivasi dan minat anak untuk melakukan eskperimen. Anak dapat membentuk bangunan sesuai dengan imajinasi yang diinginkan. Ia melakukan eksperimen menyusun bangunan rumah, menemukan konsepnya sendiri yaitu bangunan akan kokoh jika disusun dari yang besar ke kecil. Sehingga, dari APE ini aspek perkembangan akan berkembang dengan optimal.

Oleh karena itu, penggunaan APE wajib difungsikan dengan optimal oleh para guru PAUD, menurut mereka mengajar tanpa APE tidak memberikan stimulus dalam mengembangkan aspek perkembangan anak, tidak menciptakan situasi belajar yang menyenangkan, sehingga proses pemberian stimulus untuk perkembangan anak akan terhambat, tanpa ada APE kesempatan bersosialisasi, berkomunikasi dengan temannya akan terhambat. Sehingga, penggunaan APE memiliki peran penting dalam upaya menumbuh kembangkan setiap aspek perkembangan AUD. Gambaran di atas sejalan dengan George S. Morrison (2012: 88) bahwa (1) pembelajaran pada anak akan meningkat jika menggunakan materi konkret, sehingga pengajaran harus beralih dari konkret menuju abstrak, hal senada diungkapkan oleh piaget dalam Muhibbun Syah (2008: 68), yaitu anak umur 2 - 7 tahun berada pada tahap pra-operasional konkrit, di mana perkembangan otak anak hanya akan memahami sesuatu hal yang bersifat konkret. (2) mengajar merupakan proses yang sistematis dan terencana, (3) mengajar harus berpusat pada anak bukan orang dewasa, (4) mengajar harus berkolaborasi dengan anak sebagai sarana meningkatkan perkembangan. Gambaran yang sama juga diatur dalam UU No. 20 tahun 2003 SISDIKNAS yang menjelaskan bahwa pembelajaran adalah proses interaksi peserta didik dengan pendidik dan sumber belajar pada suatu lingkungan belajar. Pembelajaran interaktif merupakan proses belajar yang menimbulkan rasa ingin tahu, inovatif dan kreativitas anak. Suasana belajar yang nyaman, senang dan tidak menyeramkan. 
Berdasarkan hasil Wawancara dengan Guru di RA Al-Ihsan Tgk Chik di Adan, masalah yang terjadi saat ini guru mengeluh karena minimnya APE di sekolah, susah mendapatkan APE karena harganya mahal dan guru tersebut tidak berpikir kreatif untuk menciptakan sendiri APE. Gambaran yang tampak pada RA tersebut, penekanannya lebih pada hafalan dan mencari suatu jawaban yang benar terhadap masalah yang diberikan, tetapi proses pemikiran tinggi termasuk berpikir kreatif jarang dilatih oleh pendidik.

Gambaran problematik ini tidak hanya terjadi di Indonesia tetapi juga di Negara lain. Gambaran yang sama juga diungkapkan oleh Guilford dalam Utami (2012: 7), yaitu:

Keluhan yang paling banyak saya dengar mengenai lulusan perguruan tinggi kita ialah bahwa mereka cukup mampu melakukan tugas-tugas yang diberikan dengan menguasai teknik-teknik yang diajarkan, namun mereka tidak berdaya jika dituntut memecahkan masalah yang memerlukan cara-cara yang baru.

Berdasarkan hasil observasi awal, terlihat rendahnya perkembangan kreativitas AUD, terlihat dari guru belum menggunakan APE yang bervariasi, sehingga anak kurang termotivasi, bosan sehingga respon terhadap aktifitas perkembangan kreativitas kurang berkembang, belum terlihatnya aktifitas yang memicu anak untuk berfikir kreatif dari beberapa indikator yang tampak yaitu: guru belum membuat aktifitas pembelajaran dalam hal mengungkapkan ide/gagasannya, anak di RA tersebut belum dibiasakan untuk menciptakan sesuatu hal yang baru, baik berupa pemanfaatan bahan bekas yang dapat digunakan untuk pembuatan APE.

Menurt Rita Maharati (2017) APE memiliki peran penting "yaitu dalam melakukan pembinaan anak PAUD diperlukan sarana dan prasarana yang mandiri, guna melengkapi alatalat permainan di PAUD maupun TK”. Untuk itu, pihaknya menyerahkan alat permainan edukatif tersebut guna melengkapi permainan anak-anak di PAUD maupun TK sebagai langkah mewujudkan anak-anak yang sehat, cerdas serta ceria. Dia berharap alat permainan tersebut dapat dimanfaatkan bagi anak - anak PAUD maupun TK secara baik.

Perlu adanya tindakan inventif dan kreatif dari Guru AUD, TK/RA, mereka perlu dilatih berfikir kreatif agar dapat membuat sendiri APE sesuai dengan perkembangan anak yang disesuaikan dengan kebutuhan yang ada, seperti kurikulum, karakter anak. Sulit memunculkan ide kreatif untuk menciptakan APE sederhana, sehingga perlu adanya latihan dari awal yang dimulai dari calon guru PAUD, agar dapat menciptakan APE sederhana dari bahan bekas. 
Bahan bekas yang dimaksudkan ialah benda-benda yang pernah dipakai (sisa/bekas), yang kegunaannnya tidak sama seperti benda yang baru. Bahan bekas yang dimaksudkan ialah koran, botol plastik, kaos kaki, kain perca, kardus, kotak makanan dan minuman, gelas popmie, dll, yang ketika dikreasikan akan menghasilkan benda baru, yang memiliki fungsi lain, dan dapat dimanfaatkan untuk alat permainan dalam pembelajaran AUD.

APE dari bahan bekas merupakan salah satu alternatif dari keluhan guru saat ini, walaupun terbuat dari peralatan sederhana, tetapi alat yang dihasilkan tidak akan merubah maksud, tujuan dan fungsinya. Alat yang dikreasikan berbentuk menarik, mudah digunakan.dan sesuai dengan kriteria pembuatan APE untuk anak. Sesuai dengan pendapat Badruzzaman (2012: 8), ada 6 kriteria pembuatan APE dari bahan bekas yaitu (1) APE dirancang sesuai dengan tujuan, fungsi sarana (tidak menimbulkan kesalahan konsep (2) APE hendaknya multiguna (3) APE dibuat dengan menggunakan bahan yang mudah didapat di lingkungan sekitar, murah atau dari bahan bekas/sisa (4) menjaga keselamatan, kesehatan, dan keamanan anak (5) APE hendaknya awet, kuat dan tahan lama (5) mudah dalam pemakaian, menambah kesenangan anak untuk bereksperimen danbereksplorasi (6) dapat digunakan secara individual, kelompok dan klasikal.

Berdasarkan latar belakang masalah di atas maka peneliti tertarik untuk meneliti tentang: Penggunaan Alat Permainan Edukatif (APE) dari Bahan Bekas Untuk Meningkatkan Kreativitas AUD di RA Al-Ihsan Tgk Chik di Adan

Sumber belajar ialah bahan termasuk juga alat untuk memberikan informasi maupun keterampilan kepada siswa maupun guru untuk mendapatkan pengetahuan. Lingkungan sekitar dan hewan juga merupakan sumber belajar untuk AUD. Sumber belajar juga dapat diartikan sebagai sejumlah media yang dapat berupa alat peraga, gambar, prototip dll.

Alat peraga ialah alat bantu atau pelengkap dalam mengajar agar pembelajaran lebih efektif Nasution dalam Dwi (2010: 50), alat peraga dapat berupa benda atau perilaku yang dapat digunakan sebagai penghubung untuk memperjelas pengertian abstrak. Keberadaan alat peraga bukan untuk mengganti peran guru tetapi merupakan pelengkap atau membantu guru dalam mengajar memahami konsep dalam mempelajari sesuatu sehingga siswa mengalami keberhasilan dalambelajar. Dengan memanfaatkan alat peraga, maka pembelajaran akan lebih menyenangkan. Tujuan alat peraga ialah membantu siswa memahami konsep materi, membantu siswa untuk mencari pola agar anak menemukan sendiri jawabannya suatu permasalahan yang sedang dihadapi. Anak dilatih untuk mencoba, menemukan, memprediksi 
dari alat peraga yang ada, denganmenemukan sendiri konsep maka pengetahuan tersebut tidak akan mudah hilang, sehingga menumbuhkan logika berpikir.

Salah satu alat peraga yang dapat dimanfaatkan dalam proses pembelajaran ialah alat peraga sederhana yang dapat dibuat sendiri oleh guru. Alat peraga sederhana mempunyai karakteristik mudah ditemukan dan dibuat sendiri oleh siswa, bersama orang tua dan guru dalam kehidupan sehari-hari, bisa berasal dari bahan bekas, alat-alat rumah tangga, sampah daur ulang, Alat peraga sederhana dengan memiliki kemampuan kreativitas yang tinggi dapat juga dijadikan alat peraga edukatif dengan harga terjangkau serta penggunaan yang mudah dan dapat meningkatkan aspek perkembangan anak.

Menurut Mayke sebagaimana dikutip Badru Zaman APE ialah alat permainan yang dirancang secara khusus untuk kepentingan pendidikan. Senada dengan itu, Adang (2012) mengartikan APE sebagai perangkat alat bermain yang mengandung unsure pendidikan yang didesain secara manual, dengan memanfaatkan bahan sederhana dari sekitar, serta memiliki tujuan untuk melatih keterampilan anak.

Dunia anak tidak terlepas dari dunia bermain dan hamper semua kegiatan anak bermain mempergunakan alat permainan. Alat permainan yang digunakan ada yang dibuat khusus untuk kegiatan bermain. Alat permainan edukatif banyak ditemukan dilembagalembaga penyelenggaraan program Pendidikan PAUD.

Syarat-syarat yang perlu diperhatikan dalam memilih APE, ialah:

1. Desain mudah dan sederhana; sebaiknya desain APE mempunyai desain yang mudah dan sederhana. Hal paling penting ialah tepat dan mengena sasaran edukasi, sehingga anak tidak terbebani dengan kerumitannya.

2. Multifungsi; permainan edukasi sesuai untuk anak lelaki atau perempuan, sehingga dapat juga dibentuk sesuai dengan kreativitas dan keinginan anak

3. Menarik; APE sebaiknya mampu memotivasi anak dan tidak memerlukan pengawasan yang intensif. Sehingga anak akan bebas mengekpresikan kreativitasnya.

4. Awet dan sesuai Kebutuhan; Hendaknya permainan edukasi tahan lama dan sesuai tujuan yang diinginkan, sesuai dengan kebutuhan dan tidak menghabiskan ruang

5. Mendorong anak untuk bermain Bersama; sebaiknya memilih anak yang memberi kesempatan untuk bersosialisasi dengan temannya dengan segenap kreatiftasnya.

6. Mengembangkan daya fantasi; permainan edukasi diharapkan mampu mengembangkan daya fantasi dan imajinasi anak. 
Ciri-ciri APE adalah sebagai berikut;

1. Ditujukan untuk anak TK

2. Berfungsi mengembangkan aspek-aspek perkembangan anak TK

3. Dapat digunakan dengan berbagai cara, bentuk dan untuk bermacam-macam tujuan aspek perkembangan atau bermanfaat multi guna

4. Dirancang untuk mendorong aktifitas dan kreativitas

5. Bersifat konstruktif atau ada sesuatu yang dihasilkan

\section{APE dari Bahan Bekas yang Mengembangkan Kreativitas AUD}

Pembuatan APE merupakan suatu kegiatan yang memerlukan bekal kemampuan yang memadai. Bekal kemampuan yang dimaksudkan adalah pengetahuan dan keterampilan bagaimana melakukannya sesuai dengan persyaratan-persyaratan tertentu sehingga alat permainan edukatif yang dibuat betul-betul efektif dalam mengembangkan aspek-aspek perkembangan anak.

Ada tiga syarat pembuatan APE, yaitu (1) syarat edukatif, (2) syarat estetika, (3) syarat teknis. Berikut 2 jenis APE yang dibuat dari Bahan Bekas yang digunakan dalam penelitian ini:

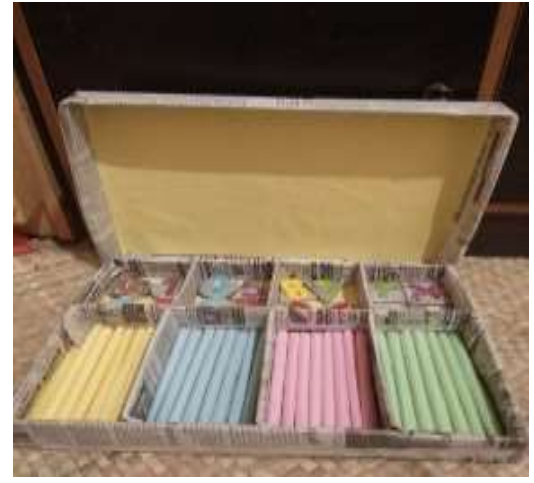

Gambar 2. APE Media berhitung koran bekas

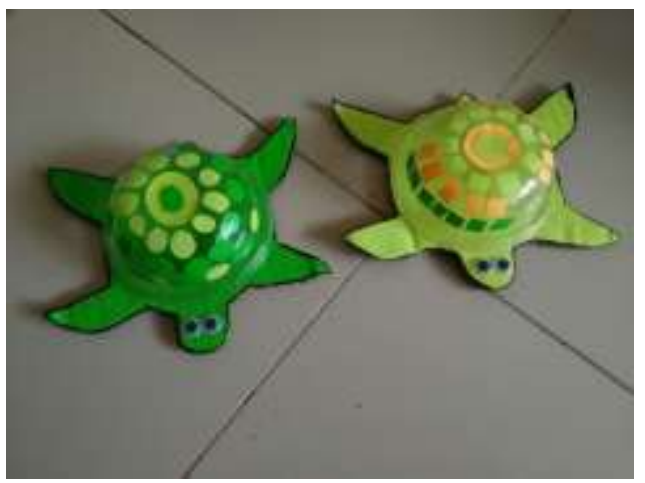

Gambar 3. APE Hewan Botol

\section{METODOLOGI PENELITIAN}

Jenis penelitian ini adalah penelitian tindakan kelas. Penelitian Tindakan kelas (PTK) yang dalam bahasa Inggris adalah Classroom Action Research (CAR). Menurut Suharsimi (2006: 89) Penelitian tindakan kelas adalah salah satu strategi pemecahan masalah yang memanfaatkan tindakan nyata dan proses pengembangan kemampuan dalam mendeteksi dan memecahkan masalah. PTK dapat diartikan juga sebagai upaya atau tindakan yang dilakukan oleh guru atau peneliti untuk memecahkan masalah pembelajaran melalui kegiatan penelitian. Intinya adalah untuk memperbaiki mutu dan hasil pembelajaran. 
Penelitian ini dilaksanakan untuk mengetahui perkembangan perubahannya yang dapat melakukan tahapan perbaikan dengan baik. PTK merupakan proses pengkajian melalui sistem berdaur dari berbagai kegiatan pembelajaran. Menurut Suharsimi (2016: 12) Secara garis besar prosedur penelitian tindakan mencakup empat daur: perencanaan (planning), tindakan (acting), pengamatan (observing), dan refleksi (reflecting).


penelitian adalah AUD yaitu siswa kelompok A yang anak didiknya berjumlah 6 anak. Pemilihan dan penentuan subjek penelitian ini yaitu untuk mengetahui peningkatan kreativitas anak secara keseluruhan.

Teknik pengumpulan data berupa observasi kreativitas anak dengan APE dari Bahan Bekas yang terdiri dari beberapa pernyataan yang menunjukkan kreativitas AUD dengan APE dari Bahan Bekas. Observasi ini berupa daftar skoring. Lembar ini diisi oleh observer saat proses pembelajaran berlangsung di dalam kelas.

Tabel. 1 Indikator Kreativitas AUD dengan APE dari Bahan Bekas

\begin{tabular}{|c|c|c|}
\hline $\mathrm{N}$ & Indikator & Aspek Yang diamati \\
\hline 1 & $\begin{array}{l}\text { Melaksanakan sesuatu dari } \\
\text { barang bekas }\end{array}$ & $\begin{array}{l}\text { Anak mampu melaksanakan kegiatan dengan } \\
\text { bahan bekas dari koran bekas atau botol plastik }\end{array}$ \\
\hline
\end{tabular}




\begin{tabular}{|c|c|c|}
\hline 2 & Memilih alternatif & $\begin{array}{l}\text { Anak mampu memikirkan sebuah benda yang akan } \\
\text { dibuat dari koran bekas atau botol plastik }\end{array}$ \\
\hline 3 & $\begin{array}{l}\text { Menciptakan sesuatu } \\
\text { (kombinasi baru) dari barang } \\
\text { bekas }\end{array}$ & $\begin{array}{l}\text { Anak mampu menciptakan sesuatu dari koran } \\
\text { bekas atau botol plastik }\end{array}$ \\
\hline 4 & $\begin{array}{l}\text { Menganalisis } \quad \text { Desain } \\
\text { Rancangan }\end{array}$ & $\begin{array}{l}\text { Anak mampu menggunakan hasil karya dari Koran } \\
\text { bekas dalam proses bermain }\end{array}$ \\
\hline
\end{tabular}

Sumber: Adaptasi dari Harsanto, R. (2005: 45) dan Jurnal Nurhayati

Tahap analisis data merupakan tahap yang paling penting dalam suatu penelitian, karena pada tahap ini akan dideskripsikan dengan menggunakan statistik deskritif adalah sebagai berikut: observasi kreativitas anak dengan APE dari Bahan Bekas sumber datanya adalah lembar observasi kreativitas anak dengan APE dari Bahan Bekas. Lembar observasi ini terdiri dari beberapa indikator dan setiap indikator mempunyai skor. Berikut tabel rubrik penilai Kreativitas AUD dengan APE dari Bahan Bekas diadopsi dari Harsanto (2005: 45).

Tabel 2. Rubrik Penilaian Kreativitas AUD dengan APE dari Bahan Bekas

\begin{tabular}{|c|c|c|c|}
\hline No & Indikator & Deskripsi & Skor \\
\hline \multirow[t]{4}{*}{1} & \multirow{4}{*}{$\begin{array}{l}\text { Melaksanak } \\
\text { an sesuatu } \\
\text { dari barang } \\
\text { bekas }\end{array}$} & $\begin{array}{l}\text { Jika anak bisa tanpa bantuan dalam melaksanakan } \\
\text { kegiatan dengan bahan bekas (koran bekas atau } \\
\text { botol plastik) }\end{array}$ & 4 \\
\hline & & $\begin{array}{l}\text { Jika anak bisa dengan sedikit bantuan dalam } \\
\text { melaksanakan kegiatan dengan bahan bekas (koran } \\
\text { bekas atau botol plastik) }\end{array}$ & 3 \\
\hline & & $\begin{array}{l}\text { Jika anak bisa dengan banyak bantuan dalam } \\
\text { melaksanakan kegiatan dengan bahan bekas (koran } \\
\text { bekas atau botol plastik) }\end{array}$ & 2 \\
\hline & & $\begin{array}{l}\text { Jika anak tidak mau mencoba dalam melaksanakan } \\
\text { kegiatan dengan bahan bekas (koran bekas atau } \\
\text { botol plastik) }\end{array}$ & 1 \\
\hline \multirow[t]{4}{*}{2} & $\begin{array}{l}\text { Memilih } \\
\text { alternatif }\end{array}$ & $\begin{array}{l}\text { Jika anak bisa tanpa bantuan dalam memikirkan } \\
\text { sebuah benda yang akan dibuat dari koran bekas } \\
\text { atau botol plastik }\end{array}$ & 4 \\
\hline & & $\begin{array}{l}\text { Jika anak bisa dengan sedikit bantuan dalam } \\
\text { memikirkan sebuah benda yang akan dibuat dari } \\
\text { koran bekas atau botol plastik }\end{array}$ & 3 \\
\hline & & $\begin{array}{l}\text { Jika anak bisa dengan banyak bantuan dalam } \\
\text { memikirkan sebuah benda yang akan dibuat dari } \\
\text { koran bekas atau botol plastik }\end{array}$ & 2 \\
\hline & & $\begin{array}{l}\text { Jika anak tidak mau mencoba dalam memikirkan } \\
\text { sebuah benda yang akan dibuat dari koran bekas } \\
\text { atau botol plastik }\end{array}$ & 1 \\
\hline 3 & \multirow{2}{*}{$\begin{array}{l}\text { Menciptaka } \\
\mathrm{n} \quad \text { sesuatu } \\
\text { (kombinasi }\end{array}$} & $\begin{array}{l}\text { Jika anak bisa tanpa bantuan dalam menciptakan } \\
\text { sesuatu dari koran bekas atau botol plastik }\end{array}$ & 4 \\
\hline & & Jika anak bisa dengan sedikit bantuan dalam & 3 \\
\hline
\end{tabular}




\begin{tabular}{|l|l|l|c|}
\hline $\begin{array}{l}\text { baru) dari } \\
\text { barang } \\
\text { bekas }\end{array}$ & $\begin{array}{l}\text { menciptakan sesuatu dari koran bekas atau botol } \\
\text { plastik }\end{array}$ & \\
\hline & $\begin{array}{l}\text { Jika anak bisa dengan banyak bantuan dalam } \\
\text { menciptakan sesuatu dari koran bekas atau botol } \\
\text { plastik }\end{array}$ & 2 \\
\hline 4 & $\begin{array}{l}\text { Menganalisi } \\
\text { Desain } \\
\text { Rancangan }\end{array}$ & $\begin{array}{l}\text { Jika anak tidak mau mencoba dalam menciptakan } \\
\text { sesuatu dari koran bekas atau botol plastik }\end{array}$ & 1 \\
\hline & $\begin{array}{l}\text { Jika anak bantuan dalam menggunakan } \\
\text { menggunakan hasil karya dari Koran bekas dalam } \\
\text { proses bermain dalam proses bermain }\end{array}$ & 4 \\
\hline & $\begin{array}{l}\text { Jika anak bisa dengan banyak bantuan dalam } \\
\text { menggunakan hasil karya dari Koran bekas dalam } \\
\text { proses bermain }\end{array}$ & 2 \\
\hline & $\begin{array}{l}\text { Jika anak tidak mau mencoba dalam dalam } \\
\text { menggunakan hasil karya dari Koran bekas dalam } \\
\text { proses bermain }\end{array}$ & 1 \\
\hline
\end{tabular}

Menentukan deskriptor butir amatan dengan pemberian skor dengan ketentuan sebagai berikut:

$4=$ jika anak bisa tanpa bantuan

$3=$ jika anak bisa dengan sedikit bantuan

$2=$ jika anak bisa dengan banyak bantuan

$1=$ jika anak tidak mau mencoba

Setelah lembar observasi diisi oleh observer saat pembelajaran berlansung, skor kreativitas anak dengan APE dari Bahan Bekas dihitung untuk masing-masing anak. Persentase perhitungan dari lembar observasi sebagai berikut:

$$
\text { Persentase }=\frac{\text { Jumlah Skor yang Dicapai }}{\text { Jumlah Skor Maksimum }} \times 100 \%
$$

Penelitian ini mengacu pada jenis penelitian tindakan kelas (PTK), yang mana keberhasilan dapat dikatakan berhasil jika adanya peningkatan dalam proses pembelajaran untuk melihat kemampuan kreativitas anak mencapai minimal $76 \%$ dari jumlah seluruh anak kelompok A, adapun hasil yang terlihat dapat diukur dari hasil Siklus I dan Siklus II.

Untuk menentukan keberhasilan dan keefektifan penelitian ini, dirumuskan indikator kinerja keberhasilan apabila telah mencapai rata - rata persentase $76 \%$. Yang berpedoman pada kurikulum di taman kanak - kanak dengan indikator sebagai berikut:

1. Melaksanakan sesuatu dari barang bekas 
2. Memilih alternatif

3. Menciptakan sesuatu (kombinasi baru) dari barang bekas

4. Menganalisis Desain Rancangan

Tabel 3. Kategori Keberhasilan Anak Didik

\begin{tabular}{|c|c|c|}
\hline Persentase & Kategori & Skor \\
\hline $0 \%-25 \%$ & Belum berkembang (BB) & 1 \\
\hline $26 \%-50 \%$ & Mulai Berkembang (MB) & 2 \\
\hline $51 \%-75 \%$ & Berkembang Sesuai Harapan (BSH) & 3 \\
\hline $76 \%-100 \%$ & Berkembang Sangat Baik (BSB) & 4 \\
\hline
\end{tabular}

Sumber: Depdiknas, Pedoman Penilaian di TK

\section{HASIL DAN PEMBAHASAN}

\section{Siklus 1}

\section{a. Perencanaan}

Peneliti dan Guru melakukan kolaborasi melakukan perencanaan untuk peningkatan kreativitas AUD dengan menggunakan APE dari bahan bekas. Dalam tahap ini peneliti dan Guru melakukan perencanaan sebagai berikut: (1) menyusun rencana pelaksanaan pembelajaran harian (RPPH) dengan tema jenis-jenis hewan dan sub tema (terlampir), (2) menyiapkan APE dari Bahan bekas dan sumber belajar yang dibutuhkan dalam proses pembelajaran, (3) Menyiapkan lembar observasi kreativitas AUD.

\section{b. Pelaksanaan}

Deskripsi awal pelaksanaan dengan menerapkan RPPH yang telah dirancang dengan menggunakan APE dari bahan bekas pada sub tema jenis-jenis hewan yang telah disesuaikan dengan waktu dan proses pembelajaran pada saat penelitian berlangsung. Adapun Langkah pelaksanaan pembelajaran diklasifikasikan pada tiga kegiatan, yaitu (1) kegiatan awal, (2) kegiatan inti, (3) kegiatan akhir.

1) Kegiatan Awal. Kegiatan awal dimulai dengan baris berbaris dengan tertib dan rapi di halaman sekolah, kemudian anak berdo'a, guru dan anak bernyanyi dan melakukan yelyel agar anak termotivasi dalam belajar, guru menyuruh beberapa anak ke depan untuk bernyanyi dan anak yang lain mengikutinya. Kemudian guru mengajak anak untuk berdoa sebelum kegiatan pembelajaran dan membaca ayat-ayat pendek. Kemudian guru melakukan absen dan menanyakan kabar anak dan aktifitas apa yang dilakukannya sebelum ke sekolah satu persatu. 
2) Kegiatan Inti. Guru mengajak anak untuk bercakap-cakap sesuai dengan tema pembelajaran hari tersebut, yaitu tema Binatang. Guru menginstruksikan langkah cycle time yaitu anak berkumpul dalam lingkaran: menyanyikan lagu-lagu tentang jenis-jenis hewan, contoh ikan, serangga, kura-kura dll, kemudian anak bergerak seperti jalannya kura-kura (merangkak), kegiatan yang akan dilakukan hari itu. Pada pijakan sebelum bermain proses mengamati dan menanya anak melakukan melakukan kegiatan membuat aneka kreasi tentang kura-kura, ikan, pada pijakan saat bermain anak mengumpulkan informasi berupa mengamati bahan-bahan yang akan digunakan untuk bermain, ada tiga kegiatan bermain; (1) melaksanakan sesuatu dari bahan bekas, anak diberikan suatu aktifitas melaksanakan kegiatan dengan menggunakan botol plastik. Anak dituntut untuk memikirkan sebuah benda yang akan dibuat dengan botol plastik, anak diberikan kesempatan untuk memilih alternatif pilihan hewan yang akan dibuatnya sendiri, dan anak dapat berandai-andai dalam imajinasinya jenis hewan apa yang dapat dibentuk dengan botol plastik. (2) menghias benda yang telah dibuat dengan menggunakan cat, menempelkan mata pada hewan tsb. (3) Anak mengerjakan sesuai dengan pilihan., bagi anak yang sudah selesai mengerjakan satu kelompok bahan bisa mengerjakan kelompok bahan yang lainnya dan kemudian anak memajang kasil karyanya. Bahan yang digunakan berupa botol plastik bekas, yang dikreasikan sesuai bentuk yang mereka sukai, dengan cara menggunting setiap botol menjadi bentuk-bentuk hewan. Kegiatan ini dilakukan untuk mengembangkan kreativitas anak dalam memikirkan dan menciptakan suatu hal.

3) Kegiatan Akhir. Pada kegiatan akhir, pijakan setelah bermain: membereskan alat main, menceritakan pengalamannya saat bermain, menceritakan perasaannya selama bermain. Guru melakukan diskusi tentang kegiatan satu hari, menyampaikan kegiatan yang akan dilakukan esok hari dan kegiatan penenangan yang berupa: lagu, cerita, berdoa, dan salam.

\section{c. Pengamatan}

Peneliti melakukan observasi (pengamatan) pada tahap proses pembelajaran anak pada siklus I. Observasi ini dilakukan untuk menjadi hasil pengamatan perkembangan kreativitas anak pada siklus I, yang dapat dilihat pada tabel berikut: 
Tabel 4. Hasil Observasi Kreativitas AUD Siklus I

\begin{tabular}{|c|c|c|c|c|c|c|c|c|}
\hline \multirow{2}{*}{ No } & \multirow{2}{*}{$\begin{array}{r}\text { Nama } \\
\text { Anak }\end{array}$} & \multicolumn{4}{|c|}{ Indikator Kreativitas Anak } & \multirow[t]{2}{*}{ Jumlah } & \multirow[t]{2}{*}{ Persentase } & \multirow[t]{2}{*}{ Kriteria } \\
\hline & & $\mathrm{A}$ & $\mathrm{B}$ & $\mathrm{C}$ & $\mathrm{D}$ & & & \\
\hline 1 & Reza & 2 & 2 & 2 & 1 & 7 & $43,75 \%$ & MB \\
\hline 2 & Fajar & 2 & 1 & 2 & 2 & 7 & $43,75 \%$ & MB \\
\hline 3 & Cut & 2 & 3 & 2 & 1 & 8 & $50 \%$ & MB \\
\hline 4 & Zara & 2 & 3 & 3 & 2 & 10 & $62,50 \%$ & $\mathrm{BSH}$ \\
\hline 5 & Ainun & 2 & 2 & 1 & 1 & 6 & $37,50 \%$ & MB \\
\hline 6 & Rika & 2 & 2 & 1 & 1 & 6 & $37,50 \%$ & $\mathrm{MB}$ \\
\hline \multicolumn{2}{|c|}{ Jumlah } & 12 & 13 & 11 & 8 & 44 & $45,83 \%$ & $\mathrm{MB}$ \\
\hline \multicolumn{2}{|c|}{ Persentase } & & & & & & $45,83 \%$ & $\mathrm{MB}$ \\
\hline
\end{tabular}

Keterangan:

A. Melaksanakan sesuatu dari barang bekas

B. Memilih alternatif

C. Menciptakan sesuatu (kombinasi baru) dari barang bekas

B. Menganalisis Desain Rancangan

Pada pelaksanaan siklus I dari 6 orang anak terlihat hanya satu orang anak yaitu Zara yang memiliki kemampuan kreativitas anak pada kategori berkembang sesuai harapan (BSH), anak yang berada pada kategori mulai berkembang yaitu Reza, Fajar, Cut, Ainun dan Rika. Agar lebih jelas peningkatan setiap anak dapat dilihat pada grafik berikut ini:

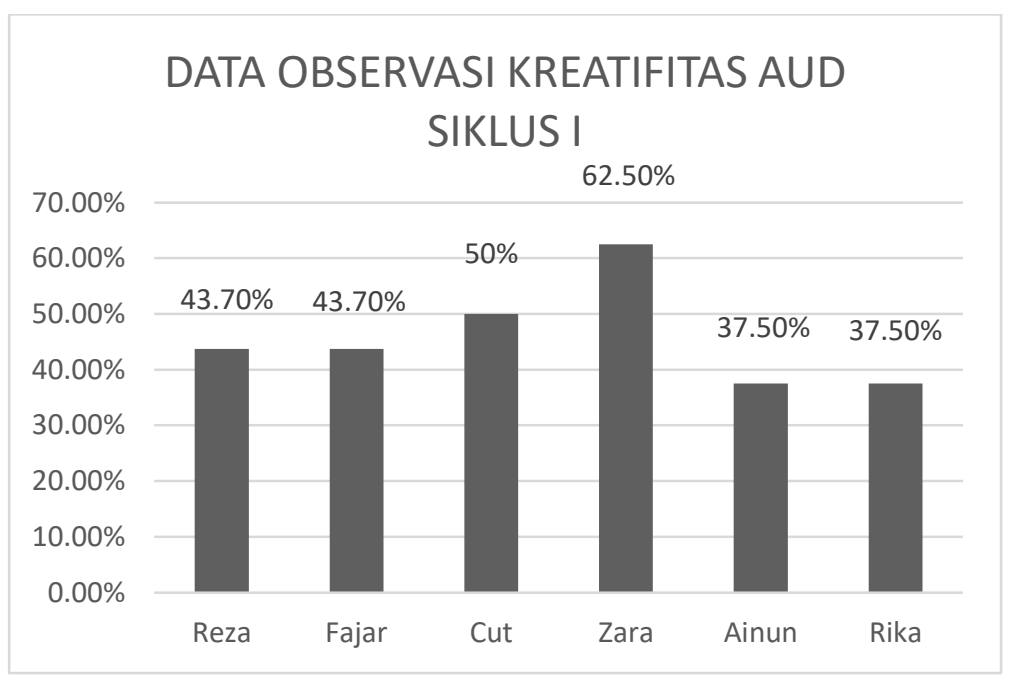

Gambar 5. Grafik Batang Data Observasi Kreativitas AUD Siklus I

Berdasarkan hasil data di atas terdapat 1 anak yang memperoleh persentase $51 \%$ $75 \%$ yaitu Zara dengan persentase $62,50 \%$, sedangkan anak yang berada pada range persentase $26 \%-50 \%$ berjumlah 5 orang anak yaitu, Reza, Fajar, Cut, Ainun dan Rika. Sehingga, berdasarkan data pada siklus I dari 6 orang anak hanya 1 anak yang sudah 
berkembang sesuai harapan, hal tersebut diindikasikan dari aktifitas pembelajaran yang diamati, yaitu; pada indikator pertama melaksanakan sesuatu dari barang bekas Zara bisa dengan banyak bantuan dalam melaksanakan kegiatan dengan bahan bekas yaitu dari botol plastik, zara melakukan suatu hal yaitu ia mampu mengotak-atik botol bekas menggunting ujung dari botol, walau dalam mengungkapkan ide masih belum tepat tetapi mampu untuk mengembangkan aspek tersebut juga dengan bimbingan Guru yaitu Ibu Eliyana dan Ibu Nazariah. Begitu juga dengan memilih alternatif Zara sudah dapat memikirkan ide yang dapat dibuat dengan menggunakan botol plastic tersebut yaitu terlihat dari aktifitas ketika Zara mulai membuka tutup botol dan menyusun satu persatu, dan mengatakan bahwa ini bisa dibentuk ular Panjang, "ini bisa dibuat ikan”.

Hasil data observasi terlihat hanya 1 orang anak yang sudah berkembang sesuai harapan, sedangkan 5 anak yang lain berada pada kategori mulai berkembang. Walaupun demikian, setidaknya anak tersebut lebih termotivasi untuk mulai menggunakan Alat Permainan Edukatif meskipun masih belum tepat dan masih dalam bimbingan guru, yang terpenting sudah munculnya rasa ingin tahu pada anak tersebut terhadap Alat Permainan Edukatif dari botol plastic, anak juga terlihat penasaran dan mencari tahu, seperti menanyakan banyak hal, Reza mulai sadar bahwa ia bisa mulai memainkan alat permainan tersebut. Ia menanyakan "terbuat dari apa ini?”, "ooh, ini bisa juga jadi kura-kura..hore”.

Pada tahap ini, selain anak antusias untuk memainkan alat, guru juga membimbing anak untuk mencari tahu alternative apa-apa saja yang dapat digunakan untuk membuat alat permainan, diharapkan anak dapat menjawab bermacam-macam jawaban, tetapi pada siklus I belum muncul jawaban dari 5 anak tersebut, anak masih terlihat bingung dan mengotak-atik APE, bahwa ada beberapa APE yang dirusak, itu menandakan rasa ketertarikan anak yang besar. Anak menanyakan: "ini dibuat dari apa", ini hewan apa? dll. Banyak pertanyaan anak yang muncul dari APE, sehingga paling tidak langkah awa; ini memicu anak untuk memcahkan rasa penasaran terhadap APE.

Pada siklus I ini terlihat kemampuan kreatif anak belum terlalu muncul, hanya 1 anak yaitu Zara yang kemampuan kreatifnya sudah mulai berkembang sesuai harapan. Zara dapat menjawab beberapa pertanyaan dari guru, karena ternyata dia pernah melihat Ibunya sendiri sedang membuat bunga-bunga dari pipet minuman, yang kemudian ia mainkan bunga-bunga tersebut, sehingga dari pengalamannya sendiri Zara mulai timbul banyak alternative jawaban. Kita dapat menciptakan APE juga dari pipet minuman, dari hal tersebut ia sudah mulai 
termotivasi untuk berpikir, walau belum sempurna. Pada zara mengungkapkan hal tersebut, guru tidak diam saja, tapi membimbing dan menggali lebih dalam terhadap pengetahuan awal Zara. Ketika ditanyakn lebih lanjut, Zara tidak dapat menjawab, dia hanya memainkan APE tersebut. Sedangkan 5 anak yang lain hanya sibuk memainkan APE lagi.

Hasil siklus I terlihat pengalaman yang dialami anak sendiri ternyata lebih mudah untuk mengembangkan kemampuan kreativitas anak, dari pada hanya melihat dan memperhatikan apa yang dijelaskan guru, guru sebaiknya dapat menghubungkan kemampuan kreatiftas anak dengan benda-benda nyata yang ada disekitar anak. Hal ini akan memudahkan anak untuk bereksplorasi dan mengembangkan kemampuan kreativitas anak tersebut. Hal ini juga menjadi pembelajaran bagi guru bahwa APE bias didapat dari lingkungan kita sendiri, terutama dari bahan bekas, sehingga ini juga dapat memotivasi guru agar lebih sering untuk menjelaskan hal konkrit pada anak, anak tidak boleh membayangkan suatu yang abstrak.

\section{d. Refleksi}

Adapun pada tahap refleksi siklus I ini dilakukan untuk mengetahui peningkatan kemampuan kreativitas anak serta mencari kendala/hambatan yang dapat menghambat proses pembelajaran khususnya untuk meningkatkan kemampuan kreativitas anak di kelompok A RA Al- Ihsan Tgk Chik di Adan.

Penjelasan tentang hasil temuan untuk aspek-aspek yang perlu diperbaiki selama siklus I berlangsung, dapat dilihat pada tabel 1.3 berikut:

\section{Tabel 5. Hasil Temuan Siklus I}

\begin{tabular}{|c|c|c|}
\hline Refleksi & Hasil Temuan & Revisi \\
\hline $\begin{array}{l}\text { Hasil } \\
\text { kreativitas } \\
\text { anak } \\
\text { siklus I }\end{array}$ & $\begin{array}{l}\text { 1. Ada } 1 \text { anak yang mencapai } \\
\text { kriteria sudah berkembang } \\
\text { sesuai harapan, yaitu: } \\
\text { dengan persentase } 62,50 \% \\
\text { perkembangan kreativitas } \\
\text { anak } \\
\text { 2. Ada } 5 \text { anak berada pada } \\
\text { kategori mulai berkembang, } \\
\text { yaitu: dengan persentase } \\
43,70 \% \text { sebanyak } 2 \text { anak, } \\
37,50 \% \text { sebanyak } 2 \text { anak } \\
\text { dan } 50 \% 1 \text { orang anak. }\end{array}$ & $\begin{array}{l}\text { Pada pertemuan ke depan, guru harus } \\
\text { lebih menfokuskan pada kreatiftas } \\
\text { anak dengan melakukan tindakan } \\
\text { konkrit berikut: } \\
\text { 1. Meningkatkan rasa penasaran } \\
\text { anak dengan menampilkan video } \\
\text { berbagai macam APE yang menarik } \\
\text { 2. Menggunakan APE jenis yang } \\
\text { lain yang terbuat dari koran bekas, } \\
\text { yaitu APE bentuk Geometri dan } \\
\text { Bilangan. Menyediakan koran bekas agar } \\
\text { 3. dapat membentuk menjadi } \\
\text { anak disukai anak } \\
\text { permainan yang disuan }\end{array}$ \\
\hline
\end{tabular}


Berdasarkan hasil temuan di atas, hal tersebut sebagai masukan pada perencanaan siklus selanjutnya. Hasil refleksi ini diharapkan akan menjadikan proses pembelajaran ke depan akan lebih baik dan kemampuan kreatiftas anak dapat meningkat dari sebelumnya pada siklus II.

\section{Siklus II}

\section{a. Perencanaan}

Berdasarkan hasil temuan dari siklus I, yaitu masih rendahnya kemampuan kreativitas anak, maka perlu adanya perencanaan perbaikan di siklus II, karena tindakan pada siklus I belum mencapai indikator keberhasilan. Perlu adanya tindakan dari Peneliti dan Guru dalam melakukan kolaborasi melakukan perencanaan untuk peningkatan kreativitas AUD dengan menggunakan APE dari bahan bekas pada siklus II. Dalam tahap ini peneliti dan Guru melakukan perencanaan sebagai berikut: (1) menyusun rencana pelaksanaan pembelajaran harian (RPPH) dengan tema jenis-jenis hewan dan sub tema (terlampir) dan materi permainan bentuk-bentuk geometri, (2) Mempersiapkan video untuk meningkatkan rasa penasaran anak dengan menampilkan video berbagai macam APE yang menarik. (3) Menggunakan APE jenis yang lain yang terbuat dari koran bekas, yaitu APE bentuk Geometri dan Bilangan. (4) Mempersiapkan koran bekas (5) Menyiapkan lembar observasi kreativitas AUD. Siklus II direncanakan dilakukan pada tanggal 3 Agustus 2018, pembelajaran dilaksanakan dari pukul $07.30-11.00 \mathrm{WIB}$.

\section{b. Pelaksanaan}

Siklus II dilakukan pada tanggal 3 Agustus 2018, pembelajaran dilaksanakan dari pukul 07.30 - 11.00 wib. Deskripsi awal pelaksanaan dengan menerapkan RPPH yang telah dirancang dengan menggunakan permainan APE bentuk Geometri dan Bilangan dari koran bekas pada sub tema jenis-jenis hewan yang telah disesuaikan dengan waktu dan proses pembelajaran pada saat penelitian berlangsung. Adapun Langkah pelaksanaan pembelajaran diklasifikasikan pada tiga kegiatan, yaitu (1) kegiatan awal, (2) kegiatan inti, (3) kegiatan akhir.

1) Kegiatan Awal. Kegiatan awal dimulai dengan senam pagi dilanjutkan dengan baris berbaris dengan tertib dan rapi di halaman sekolah, sebelum pembelajaran dimulai, guru mengajak anak bernyanyi dan melakukan yel-yel agar anak termotivasi di awal pembelajaran, guru menyuruh beberapa anak ke depan untuk bernyanyi dan anak yang lain mengikutinya. Kemudian guru mengajak anak untuk berdoa sebelum kegiatan 
pembelajaran dan membaca ayat-ayat pendek. Kemudian guru melakukan absen dan menanyakan kabar anak dan aktifitas apa yang dilakukannya sebelum ke sekolah satu persatu dan dilanjutkan dengan pembahasan tema untuk hari itu,

2) Kegiatan Inti. Guru mengajak anak untuk bercakap-cakap sesuai dengan tema pembelajaran hari tersebut, yaitu tema jenis-jenis hewan. Guru menginstruksikan langkah cycle time yaitu anak berkumpul dalam lingkaran: menyanyikan lagu-lagu tentang jenisjenis hewan, contoh, Guru menjelaskan ada hewan di darat ada hewan di laut ada hewan di udara. kemudian anak mempraktekkan setiap jenis-jenis hewan, seperti burung, anak mulai mengepakkan sayapnya dan bergerak cara terbang burung, berputar kesana-kemari, kegiatan yang akan dilakukan hari itu. Kemudian guru menyuruh siswa mengamati APE yang dibawa, yaitu APE bentuk geometri yang terbuat dari lilitan koran bekas. Guru mengajak anak untuk bermain dengan APE bentuk geometri, guru mengajak anak untuk memperhatikan APE tersebut terbuat dari apa, dan anak diajarkan nama-nama beberapa macam bentuk geometri. Lalu anak melakukan proses menghitung dari APE yang diberikan. Tahap selanjutnya anak diberikan koran-koran bekas, dan mereka diberi kesempatan untuk mengkreasikan sesuai keinginan mereka, membuat burung, bola, dan bentuk-bentuk yang lain.

Ada tiga kegiatan bermain; (1) melaksanakan sesuatu dari bahan bekas yaitu koran bekas, anak diberikan suatu aktifitas melaksanakan kegiatan dengan menggunakan koran bekas. Anak dituntut untuk memikirkan sebuah benda yang akan dibuat dengan koran bekas, anak diberikan kesempatan untuk memilih alternatif pilihan benda yang akan dibuatnya sendiri, dan anak dapat berandai-andai dalam imajinasinya jenis benda apa yang dapat dibentuk dengan koran bekas. (2) menghias benda yang telah dibuat dengan menggunakan cat. (3) Anak mengerjakan sesuai dengan pilihan., bagi anak yang sudah selesai mengerjakan satu kelompok bahan bisa mengerjakan kelompok bahan yang lainnya dan kemudian anak memajang kasil karyanya. Bahan yang digunakan berupa koran bekas, yang dikreasikan sesuai bentuk yang mereka sukai, dengan cara menggunting, melilit, memotong, melipat setiap koran menjadi bentuk-bentuk yang mereka inginkan. Kegiatan ini dilakukan untuk mengembangkan kreativitas anak dalam memikirkan dan menciptakan suatu hal.

3) Kegiatan Akhir. Pada kegiatan akhir, pijakan setelah bermain: membereskan alat main, menceritakan pengalamannya saat bermain, menceritakan perasaannya selama bermain. 
Guru melakukan diskusi tentang kegiatan satu hari, menyampaikan kegiatan yang akan dilakukan esok hari dan kegiatan penenangan yang berupa: lagu, cerita, berdoa, dan salam.

\section{c. Pengamatan}

Peneliti melakukan observasi (pengamatan) pada tahap proses pembelajaran anak pada siklus I. Observasi ini dilakukan untuk menjadi hasil pengamatan perkembangan kreativitas anak pada siklus I, yang dapat dilihat pada tabel berikut:

Tabel 6 Hasil Observasi Kreativitas AUD Siklus II

\begin{tabular}{|c|c|c|c|c|c|c|c|c|}
\hline \multirow{2}{*}{ No } & \multirow{2}{*}{$\begin{array}{l}\text { Nama } \\
\text { Anak }\end{array}$} & \multicolumn{4}{|c|}{ Indikator Kreativitas Anak } & \multirow[t]{2}{*}{ Jumlah } & \multirow[t]{2}{*}{ Persentase } & \multirow[t]{2}{*}{ Kriteria } \\
\hline & & A & B & $\mathrm{C}$ & $\mathrm{D}$ & & & \\
\hline 1 & Reza & 2 & 3 & 3 & 3 & 11 & $68,7 \%$ & $\overline{\mathrm{BSH}}$ \\
\hline 2 & Fajar & 2 & 2 & 2 & 3 & 9 & $56,25 \%$ & $\overline{\mathrm{BSH}}$ \\
\hline 3 & Cut & 4 & 3 & 4 & 3 & 13 & $81,25 \%$ & $\mathrm{BSH}$ \\
\hline 4 & Zara & 3 & 4 & 4 & 3 & 14 & $87,50 \%$ & BSB \\
\hline 5 & Ainun & 3 & 3 & 4 & 3 & 13 & $81,25 \%$ & BSB \\
\hline 6 & Rika & 2 & 4 & 4 & 3 & 13 & $81,25 \%$ & BSB \\
\hline \multicolumn{2}{|c|}{ Jumlah } & 16 & 19 & 16 & 16 & 70 & & \\
\hline \multicolumn{2}{|c|}{ Persentase } & & & & & & $76,04 \%$ & BSB \\
\hline
\end{tabular}

Keterangan:
A. Melaksanakan sesuatu dari barang bekas
B. Memilih alternative
C. Menciptakan sesuatu (kombinasi baru) dari barang bekas
D. Menganalisis Desain Rancangan

Pada pelaksanaan siklus II dari 6 orang anak terlihat ada 4 orang anak yang berada pada kategori berkembang sangat baik (BSB), yaitu Zara, Cut, Rika dan Ainun. Sehingga adanya peningkatan kreativitas anak yaitu pada siklus I hanya ada 1 orang anak yaitu Zara yang memiliki kemampuan kreativitas anak pada kategori berkembang sesuai harapan (BSH). Agar lebih jelas peningkatan setiap anak dapat dilihat pada grafik berikut ini: 


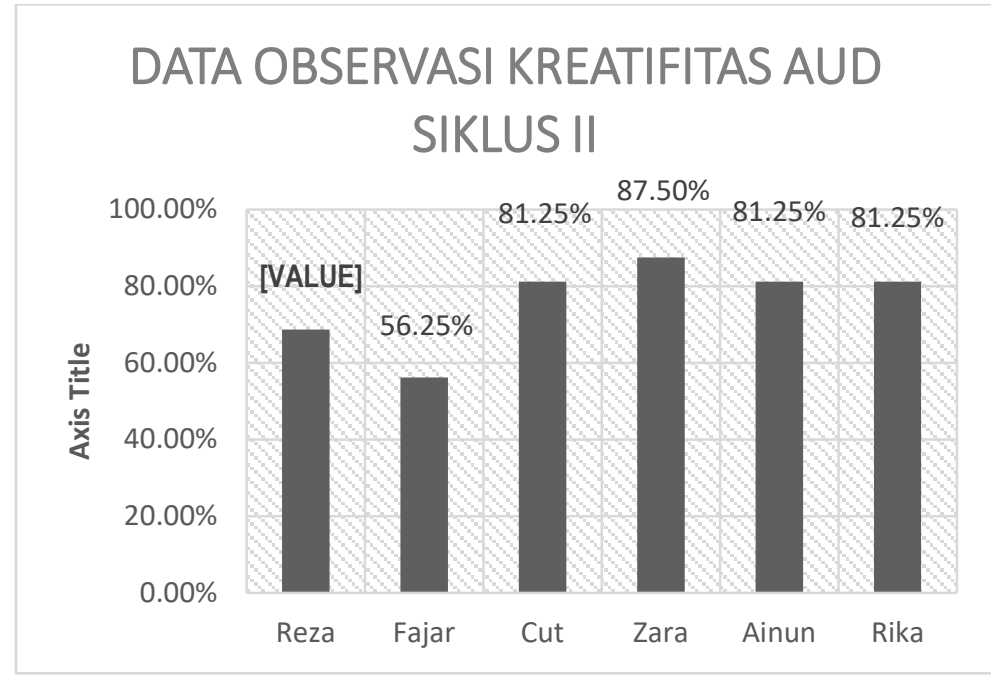

\section{Gambar 6. Grafik Batang Data Observasi Kreativitas AUD Siklus II}

\section{d. Refleksi}

Penjelasan tentang hasil temuan untuk aspek-aspek yang perlu diperbaiki selama siklus II berlangsung, dapat dilihat pada tabel 1.5 berikut:

\section{Tabel 7. Hasil Temuan Siklus II}

\begin{tabular}{|c|c|c|}
\hline Refleksi & Hasil temuan & Revisi \\
\hline $\begin{array}{l}\text { Hasil } \\
\text { kreativitas } \\
\text { anak siklus II }\end{array}$ & $\begin{array}{l}\text { 1. Ada } 4 \text { anak yang } \\
\text { mencapai kriteria } \\
\text { sudah berkembang } \\
\text { sangat baik, yaitu: } \\
\text { dengan persentase } \\
\text { masing-masing Cut: } \\
81,25 \% \text {, Zara: } \\
87,50 \% \text {, Ainun dan } \\
\text { Rika: } 81,25 \% \\
\text { 2. Ada } 2 \text { anak berada } \\
\text { pada kategori BSH, } \\
\text { yaitu: dengan } \\
\text { persentase 68,75\% } \\
\text { dan 56,25\% anak } \\
\text { berada pada } \\
\text { kategori mulai } \\
\text { berkembang yaitu } \\
\text { persentase 50\%. }\end{array}$ & $\begin{array}{l}\text { Pada pertemuan ke depan, guru harus lebih } \\
\text { menfokuskan pada kreatiftas } 2 \text { anak yang } \\
\text { masih berada pada kategori BSH dengan } \\
\text { melakukan tindakan konkrit berikut: } \\
\text { 1. Pembelajaran sudah harus melibatkan anak } \\
\text { untuk mengasah kreativitas AUD } \\
\text { 2. APE yang digunakan harus lebih menarik } \\
\text { dan memotivasi anak } \\
\text { 3. Untuk } 2 \text { anak yang belum mencapai BSB, } \\
\text { maka proses pembelajaran harus terus } \\
\text { dilakukan lebih intensif di luar penelitian } \\
\text { ini, khususnya guru melakukan beberapa } \\
\text { aktifitas untuk mengembangkan } \\
\text { kreativitasnya } \\
\text { 4. Guru tidak boleh mendiskriminasikan anak, } \\
2 \text { anak ini terlihat didiskriminasikan oleh } \\
\text { Guru, sehingga mereka sama sekali tidak } \\
\text { antusias dalam melakukan aktifitas } \\
\text { pembelajaran. } \\
\text { 5. Pemberian reward bagi anak dapat } \\
\text { membuat anak sabar dalam beraktifitas. }\end{array}$ \\
\hline
\end{tabular}


Hasil refleksi ini diharapkan akan menjadikan proses pembelajaran ke depan akan lebih baik dan kemampuan kreatiftas anak dapat meningkat dari sebelumnya pada siklus II.

\section{PEMBAHASAN}

Penelitian yang dilakukan ini menggunakan jenis penelitian tindakan kelas yang dilakukan dalam 2 siklus yaitu Siklus I dan Siklus II. Berdasarkan data hasil penelitian diperoleh bahwa aktifitas pembelajaran AUD dari hasil pengamatan adanya peningkatan kemampuan kreativitas AUD dari Siklus I berada pada kategori MB (Mulai Berkembang) yaitu 45,83\% terjadi peningkatan di Siklus II yang berada pada kategori BSB (Berkembang Sangat Baik) yaitu persentase sebesar 76,04\%. Berdasarkan hasil terbukti adanya peningkatan yang signifikan antara Siklus I dan Siklus II.

Siklus I anak masih berada pada kategori MB (mulai berkembang) dengan persentase 45,83\%, terbukti dari hasil pengamatan pada pelaksanaan siklus I dari 6 orang anak terlihat hanya satu orang anak yaitu Zara yang memiliki kemampuan kreativitas anak pada kategori berkembang sesuai harapan (BSH), sedangkan anak yang lain hanya berada pada kategori mulai berkembang yaitu Reza, Fajar, Cut, Ainun dan Rika. Hal tersebut ditandai dari aktifitas pembelajaran yang diamati pad siklus I, yaitu; pada indikator pertama melaksanakan sesuatu dari barang bekas Zara bisa dengan banyak bantuan dalam melaksanakan kegiatan dengan bahan bekas yaitu dari botol plastik, Zara melakukan suatu hal yaitu ia mampu mengotak-atik botol bekas menggunting ujung dari botol, walau dalam mengungkapkan ide masih belum tepat tetapi mampu untuk mengembangkan aspek tersebut juga dengan bimbingan Guru yaitu Ibu Eliyana dan Ibu Nazariah. Begitu juga dengan memilih alternatif Zara sudah dapat memikirkan ide yang dapat dibuat dengan menggunakan botol plastic tersebut yaitu terlihat dari aktifitas ketika Zara mulai membuka tutup botol dan menyusun satu persatu, dan mengatakan bahwa ini bisa dibentuk ular Panjang, "ini bisa dibuat ikan". Tetapi pada indicator yang lain Zara belum berkembang sesuai harapan. Sedangkan 5 anak lainnya masih pasif, hanyak duduk, diam, ketika ditanyakn baru menjawab, sehingga indicator kreativitas anak yang lain MB (mulai berkembang).

Hasil Siklus II dari 6 orang anak terlihat ada 4 orang anak yang berada pada kategori berkembang sangat baik (BSB), yaitu Zara, Cut, Rika dan Ainun. Sehingga adanya peningkatan kreativitas anak yaitu pada siklus I hanya ada 1 orang anak yaitu Zara yang memiliki kemampuan kreativitas anak pada kategori berkembang sesuai harapan (BSH). Ada 4 anak yang mencapai kriteria sudah berkembang sangat baik, yaitu: dengan persentase 
masing-masing Cut: 81,25\%, Zara: 87,50\%, Ainun dan Rika: 81,25\%. Hasil di Siklus II dapat meningkat karena temuan-temuan permasalahan di Siklus I dicoba untuk diberikan tindakan-tindakan persuasif dan konkrit yang akan dideskripsikan dalam 4 langkah berikut ini.

Tindakan 1 (Pertama) guru dalam proses Pembelajaran sudah melibatkan anak untuk mengasah kreativitas AUD, ditandai dengan guru menfasilitasi anak dengan memberikan 2 contoh APE dari bahan bekas yaitu jenis-jenis hewan dari botol plastic dan APE bentuk Geometri dan Bilangan yang selanjutnya guru memulai aktifitas pembelajaran dengan memberikan koran bekas dan anak dapat mengekspresikan ide-ide imajinatifnya, dari contoh tersebut anak diharapkan dapat membuat sendiri alat permainan yang sederhana sesuai keinginannya.

Hal di atas sesuai dengan pendapat Dwi Prasetiyawati D.H, dkk yang mengungkapkan pendapat bahwa Anak-anak membutuhkan kesempatan untuk bermain imajinatif, mengekspresikan diri, menemukan masalah, menyelidiki jalan alternatif, dan menemukan penemuan baru untuk mempertinggi perkembangan kreativitas. Untuk itu guru perlu memfasilitasi dengan memberikan berbagai kegiatan dan lingkungan belajar yang fleksibel serta berbagai sumber belajar. Kesempatan yang diberikan dapat mendorong timbulnya ekspresi diri anak. Guru dapat memberikan dorongan pada anak untuk memilih aktivitasnya sendiri, menemukan berbagai hal alternatif, dan untuk menciptakan objek atau ide baru yang memudahkan perkembangan kemampuan berpikir berbeda, dan penanganan masalah yang orisinil.

Tindakan ke 2 (dua) Penggunaan Bahan Bekas baik dari Koran Bekas atau Botol Plastik membuat motivasi anak untuk berkreativitas lebih meningkat. Hal ini sesuai dengan pendapat Gin Gin (2014: 5), yaitu dengan pemanfaatan barang bekas anak dapat membangun dan meningkatkan kreativitasnya sendiri, anak juga dapat menuangkan imajinasi kreatif dalam menghias, anak bisa memanfaatkan bahan yang alami dan mudah didapat, serta pemanfaatan barang bekas juga dapat melatih anak untuk menjaga lingkungan sekitar.

Tindakan ke 3 (tiga) guru sudah melakukan langkah nyata dengan lebih menfokuskan pada kreativitas anak dengan melakukan tindakan konkrit berikut, yaitu meningkatkan rasa penasaran anak dengan menampilkan berbagai macam APE yang menarik seperti APE jenis hewan dari Botol plastik dan menggunakan APE jenis yang lain 
yang terbuat dari koran bekas, yaitu APE bentuk Geometri dan Bilangan. Pengunaan APE dari Bahan Bekas salah satu bentuk kreatif dari guru untuk mengembangkan kemampuan kreatiftas AUD. Mayke Sugianto dalam Eka Sri berpendapat bahwa Alat Permainan Edukatif (APE), alat permainan yang sengaja dirancang secara khusus untuk kepentingan pendidikan. (Mayke Sugianto, 1995). Sementara Direktorat PAUD (2003) menyebutkan bahwa Alat Permainan Edukatif (APE) adalah segala sesuatu yang dapat dipergunakan sebagai sarana atau peralatan untuk bermain yang mengandung nilai pendidikan (edukatif) dan dapat mengembangkan seluruh kemampuan anak, salah satunya dapat mengembangkan kreaftifitas AUD.

Adapun tindakan ke 4 (empat) dengan menyediakan koran bekas agar anak dapat membentuk dan memberi kesempatan anak untuk berimajinasi menjadi permainan yang disukai anak. Rasa senang anak terhadap pembelajaran menunjukkan bahwa pembelajaran ini menimbulkan rasa menarik bagi anak. Mudhoffir (1987: 164) berpendapat bahwa keefektifan juga dapat diukur dengan melihat minat anak terhadap kegiatan pembelajaran. Minat dan rasa senang anak juga disebabkan oleh adanya kesempatan yang diberikan kepada anak untuk bekerja sama dalam kelompok dalam menyelesaikan aktifitas yang diberikan oleh Guru.

\section{DAFTAR PUSTAKA}

Adang. (2012). Education Games. Yogyakarta: Pro-u media.

Badruzzaman, (2006). Pengembangan Alat Permainan Edukatif Untuk Anak Taman Kanak-

Kanak, Seminar dan Pelatihan Guru-Guru Taman Kanak-Kanak (TK), Seminar

Nasional Program Pendidikan Guru Taman Kanak-Kanak (PGTK) Fakultas Ilmu

Pendidikan. Hal. 8. Bandung: Universitas Pendidikan Indonesia.

Badru Zaman. (2012). Media dan Sumber Belajar TK. Jakarta: Universitas Terbuka.

Dwi Prasetiyawati D.H, dkk, 2011, Upaya Identifikasi Kreativitas Kader-Kader PAUD di Kecamatan Ungaran melalui APE, Jurnal Penelitian PAUDIA, Volume 1 No. 1, h. 67

Dwi Yulianti. (2010). Bermain sambil belajar Sains. Jakarta: PT. Indeks.

Eka Sri Hendayani, (2006), Pemanfaatan Alat Permainan Edukatif (APE) dalam Pembelajaran

PAUD Seatap Margaluyu Kecamatan Cipatat Kabupaten Bandung Barat, Bandung.

Gordon dan Browne dalam Moeslichatoen (2004

George S. Morrison. (2012). Dasar-dasar Pendidikan Anak Usia Dini (PAUD). Texas: University of North Texas. Jakarta: PT. Indeks Jakarta.

Gin Gin Nugraha, 2014, Meningkatkan Kreativitas pada Anak Usia Dini Melalui Kegiatan Menghias Barang Bekas dengan Media Dasar Batok Kelapa, Universitas Pendidikan Indonesia | repository.upi.edu |perpustakaan.upi.edu peserta, h. 5

Hass, Glen,et.all. (1993). Curriculum Planning, A New Approach. Boston; Allyn and Bacon. Harsanto, R. (2005). Melatih Anak Berpikir Analitis, Kritis dan Kreatif. Jakarta: Grasindo. 
Ika Budi Maryatun. (2013). "Pemanfaatan bahan bekas untuk membuat Alat Permainan Edukatif (APE) di PAUD",

Langrehr, J. (2006). Thinking Skill. Alih bahasa Emilia S. A. Jakarta: Gramedia.

Martunis, Peningkatan Kreativitas Anak Melalui Melukis Menggunakan Sikat Gigi taman Kanak-kanak Padang, Jurnal Pesona PAUD Vol. 1 No. 1.

Mudhoffir, (1987). Teknologi Instruksional, (Bandung: Remadja Rosdakarya.

Muhibbun Syah. (2008). Psikologi Pendidikan dengan Pendekatan Baru. Bandung: PT. Rema ja Rosdakarya.

Nurhayati, Peningkatan Kreativitas Anak Usia Dini dengan Bereksplorasi Melalui Koran Bekas di Taman Kanak-kanak Aisyiyah, Jurnal Pesona PAUD, Vol.1. No. 1, h. 1

Suharsimi Arikunto. (2006). Prosedur Penelitian Suatu Pendekatan Praktik, (Jakarta: Rineka Cipta)

Suharsimi Arikunto, dkk., (2012). Penelitian Tindakan Kelas, (Jakarta: PT Bumi Aksara.

Suyadi dan Maulidya Ulfah. (2016). Konsep Dasar PAUD. (Bandung: PT. Remaja Rosdakarya Bandung).

UU No. 20 Tahun 2003 SISDIKNAS.

Utami Munandar. 2012. Pengembangan Kreativitas Anak Berbakat. (Jakarta: PT. Rineka Cipta. 